\title{
EVOLUTION OF LYRICAL IMAGE IN BALLETS OF AZERBAIJANI COMPOSERS
}

\author{
Lala Huseynli \\ Senior Lecturer; ORCID: 0000-0003-4158-1828; e-mail: I.d.hadjieva@gmail.com \\ Baku Academy of Choreography, Baku, Azerbaijan
}

\begin{abstract}
This article is devoted to the study of the evolution of the lyrical image in the ballets of Azerbaijani composers. The presented article emphasizes that the Azerbaijani ballet on the extension of the history of the Azerbaijani school of composition functioned indefinitely as an important component of the Azerbaijani musical culture. The theme of this article is actualized in the aspect of the historical approach, as each ballet of Azerbaijani composers, on the other hand, reflected the significant features of the artistic, historical and cultural context. On the other hand, the study of the evolution of the lyrical image in the Azerbaijani ballets reflects the dynamics of the development of the Azerbaijani school of composition. Moreover, the figurative system in Azerbaijani ballets represents the slender line of artistic connections of Azerbaijani culture. The purpose of the research is to study the role of the lyrical image in the evolution of the Azerbaijani ballet. The research methodology is based is based on the use of a historical approach to determine the basic definitions of the study. The expediency of the historical method is due to the fact that the development in the space of historical time should be based on certain basic categories that would reflect the school of composition, its national specifics. The scientific novelty of the research is that for the first time the peculiarities of the evolution of the lyrical image in Azerbaijani ballets - from its origin to modern functioning - are analyzed; the nuances of style creation in the Azerbaijani school of composers in the specified aspect are considered, and also certain art processes are systematized. Conclusions. It is proved that the combination of deep lyricism with dramatic emotions is characteristic of the transfer of lyricism in the drama of ballets at all historical stages of development, in different stylistic contexts. Lyrical images in the ballets of Azerbaijani composers have similar features and are due to the specific content of the national worldview.
\end{abstract}

Keywords: ballet; lyric; image; evolution; music; history; culture; composer

\section{Introduction}

Azerbaijani ballet on the extension of the history of the Azerbaijani composition school has functioned indefinitely as an important component of the Azerbaijani musical culture. Composers of all generations devoted themselves to ballet, turning to this kind of musical theatre. The history of Azerbaijani music has in its treasure trove such 
masterpieces as the ballet "Maiden's Tower" by Afrasiab Badalbeyli, "Seven beauties" by Kara Karaev, "1001 nights" by Fikret Amirov, "Legend of Babeken" by Arif Malikov. The scientific novelty of the enterprise, which is included in this article, is that the first analyzes the peculiarities of the evolution of the lyrical image in the Azerbaijani ballets - from the awakening to its modern functionality; the nuances of stylization in the Azerbaijani composition school are considered in the specified aspect, and also certain artistic processes are systematized.

\section{Purpose of the article}

The purpose of the research is to study the role of the lyrical image in the evolution of the Azerbaijani ballet.

\section{Recent research and publications analysis}

The study of the lyrical image evolution in ballets of Azerbaijani composers was facilitated by the works of E. Abasova $(2000,2004)$, namely 'On innovative tendencies in the work of Kara Karaev', 'The role of Arif Melikov in the development of the composing school of Azerbaijan', the works devoted to the harmonic language of the composing school of Azerbaijan, the theoretical works of R. Aliyev (1991), R. Kosacheva (1984), G. Mahmudova (2006), S. Skrebkov (1973).

\section{Main research material}

The lyrical image system, which was recorded in the ballets of Azerbaijani composers, defined a whole range of associations associated with the high spirituality of the Azerbaijani people. It is for this reason that musical lyrical characteristics in Azerbaijani ballets play a huge role in the dramaturgy of ballets and become clear ideas, leitmotifs, determine the important points of content in ballets. Lyrical images in Azerbaijani ballets have a table of high specific weight, which acquire the meaning of the symbols of the figurative system of Azerbaijani art.

The study of lyrics in the development of Azerbaijani ballet reveals the opportunity to study the process of styling in Azerbaijani professional music. And the problems of the formation of the national style in the context of the Azerbaijani school of composition are the most pressing problems of Azerbaijani musicology. It is necessary to follow the logical chain of awakening and development of national style, unconditionally, the necessary aspect and research of the problem of modern art.

The lyrical image is remarkable with subtle nuances of expressiveness, and theatricality enhances the aesthetic properties of the lyrical image of the effect on the listener. Against the background of bright figurative characteristics in the dramaturgy of ballets, lyricism is distinguished by subtlety, sophistication, emotional depth.

And also, some general features of the musical expression of the Azerbaijani folk music, performed in the Azerbaijani ballets.

1. The descending dynamic profile of melodies - this is a bright feature that belongs to all lyrical genres of Azerbaijani folk music from the rhyming and lyrical songs of the 
Azerbaijani mugam. This important characteristic is based on the low displacement of the support steps. At the same time, the dynamics of ladointonation is enhanced by the movement of the lower tonic.

2. Ornamental specificity of melodism. The ornamental principle of positioning and development of melody is the basic morphological system of art in Azerbaijan. In this sense, ornamentation in music represents the process of enriching the melody with subtle expressive intonation nuances in the system of passing and auxiliary sounds;

3. Descending chains of sequences, creating in the melody of lyrical themes the necessary rhythm, are a characteristic feature of the national lyrical melody;

4. The lyrical verse of Azerbaijan differs in the brightness of the initial thematic 'application'. It is the main intonation that lays the 'program' of the lyrical image and its development. Sufficiently often a bright emotional effect is achieved at the beginning of the peak tone.

5. The melodic outline of the lyrical expression is plastic, its expressiveness rests on the subtle nuances of ladointonation, wavy melodic lines enhance emotional expressiveness.

6. Special relief of lyrical melodies are acquired as a result of the whole 'loop' of growths.

The support of the national semantics in the ballets of Azerbaijani composers represents a deep understanding of the meaning of Azerbaijani folk music. With greater sensitivity, aesthetically more focused on the perception of the national layer in music there is a ladointonation system.

We sum up some means of expressing lyrics in Azerbaijani music:

1. Variation of ladofunctional coordination with the stem;

2. Expressiveness of cadences and their ostinato-dramatic repetition;

3. Special qualities of material development, lyrical methods of development;

4. Methods of development of the main range;

5. Dynamics of growth of intensifying lyrical image development;

6 . Features of the development of the main thematic grain - the first impulse of the lyrical image;

7. Ornamentality as an effective method of lyricization of the text.

The richness and multiplicity of lyrical images in the ballets of Azerbaijani composers are connected with the specifics of the national character, the priorities of mentality, the peculiarities of the individual style of Azerbaijani composers and other factors. Lyrical forms of expression in Azerbaijani ballets are multifaceted and closely related, unambiguously, with meaning and dramatic embodiment of the main idea and plot, with the peculiarities of the musical language, which determines the expressive expression. The peculiarities of lyrical expression in the ballets of Azerbaijani composers are reflected in the high weight of lyric content, the maximum level of emotional expression. The specific style of the composer dictates this or that type of lyrical image. And in the history of the Azerbaijani ballet is recorded a wide range of lyrical imagery. Together with the wholeness of the Azerbaijani musical culture, the national specificity of the artistic culture, the unity of the sources and stages of development of the Azerbaijani school of music determine a single circle and the peculiarities of the Azerbaijani lyric poetry, the lyrics of our songs: 
1. Significant role of traditional lyrical foundations in Azerbaijani art culture;

2. Sustainability of expression of lyrical semantics as a national slang culture;

3. Depth of moral characteristics, the maximum degree of expression of spirituality;

4. The role of lyrical-dramatic expression in the characterization of female images in the ballets of Azerbaijani composers;

5. Reflection of traditional lyrical bases in a modern stylistic context, in terms of artistic innovations.

Naturally, that the birth of a new form of professional music for the Azerbaijani theatrical genre is due to itself and the birth of new forms of expression, closely related to the language of choreography, theatrical performance, dramaturgy. Thus, in the creation of the ballet $A$. Badalbeyli relied on and performed in his individual style of Azerbaijani folk melodies. The main thing for us is the individualization of lyrical imagery, which allowed the composer to lay the foundations of a definite, nationally conditioned drama. For example, the tragicness of the lyrical image intersects the national musical material and raises it to the professional level of authorial communication.

It is important to note that the music of the first ballet in the history of Azerbaijani was formed a lyrical image as a semantic and compositional centre of ballet, possessing an impressive force of action.

Aesthetic universals of lyrical images by Nizami Ganjavi were reflected in the figurative system of Kara Karaev's ballet 'Seven beauties'.

As the analysis showed, the lyrical structure of the image of the Seven beauties operates on the intonations of the complex hierarchical system of intonation intonations, including the increased seconds. The fullness of the existence of musical lyrical images is revealed at the level of such a charm as chargyah. Let us recall that chargyahs in their semantics are able to express not only lyrical but also a dramatic sphere. We emphasize that the intonation of the extended seconds are the main themes that characterize the Seven beauties, as well as the developing and concluding parts of the development of lyrical scenes.

The chromatic nuance of the 'Adagio Aisha and Bahram' theme is dynamic from a functional point of view. The nuances of the altered steps are thought out and laconic. And, at the same time, it is precisely the economy of expressive means that conveys the power of lyrical energy in a concentrated manner. Let me emphasize that the comparison of diatonic and chromatic elements is not only 'visual' in nature of auxiliary sounds. A complex multifunctional system of horizontal and vertical conjugation is concentrated here. Thus, in the harmonization of the first and second elements of the theme, the rise of the 8th degree, which is characteristic of the segyah mode, is alternately reproduced, that is, si-flat - si-natural. As a result, an interval of a reduced octave is formed between the melody and the harmonic accompaniment. Further, such a bright dissonance in the third element turns into the melodic structure of the third element.

The most striking and specific feature of the lyrical image in the ballet 'Seven Beauties' is a high artistic generalization. The latter highlights lyrical images in ballet as one of the main vectors of drama. It is this quality that allows one to explore the characteristic properties of the lyrical image in the ballet 'Seven Beauties' as an evolutionary stage in the process of the composer's style. Let us emphasize that the study of 
lyricism in Azerbaijani ballets requires a special approach. Lyrical imagery appears in every ballet. In each ballet, the lyrics take on individual features depending on the era and style of the composer. The creation of each new ballet was accompanied by the birth of certain new forms in the history of Azerbaijani ballet.

Turning to the lyrics in Azerbaijani ballets, we note that the lyrics create semantic correlations in the context of ballets that hold together the form and drama of the ballet as a whole. The above is comparable with Arif Melikov's ballet 'The Legend of Love'.

The semantics of the musical expressiveness of lyrical images in the ballet 'The Legend of Love' by Arif Melikova is complex, has both individual and genetic character. It is about reliance on lyrical expressiveness, which was formed in the context of Azerbaijani professional music.

'Adagio Farhada and Shirin' seems to embody several aspects of the lyrical content. Here there is a high lyrical feeling, nobility, restraint of emotions, and a 'high point' of the intensity of passions, and an exquisite, flexible lyrical lightness of a light joyful feeling. The specificity of intonational positioning is multifunctional. Here is a lyrical chant, and mournful intonations, and an emotional outburst of feelings. One can also observe a figurative transformation from a quiet chant to lyrical pathos. Thus, the expressive culmination is based on the main theme 'Adagio'. The lyric and dramatic content of 'Adagio Farhad and Shirin' is clearly revealed in the juxtaposition of emotional blocks. Thanks to this development, 'Adagio Farhada and Shirin' is permeated with movement, and the emotional 'colour' is deeply personal.

Turning to the interpretation of the lyrical image in the ballets of contemporary Azerbaijani composers, let us note the national specificity and integrity of the lyrical image in the ballets 'Babek' and 'Waltz of Hope' by Akshin Alizade. The chromatic nuance of the Adagio Aisha and Bahram theme is dynamic from a functional point of view. The nuances of the altered steps are thought out and laconic. And, at the same time, it is precisely the economy of expressive means that conveys the power of lyrical energy in a concentrated manner. Let me emphasize that the comparison of diatonic and chromatic elements is not only "visual" in nature of auxiliary sounds. A complex multifunctional system of horizontal and vertical conjugation is concentrated here. Thus, in the harmonization of the first and second elements of the theme, the rise of the VIIIth degree, which is characteristic of the segyah mode, is alternately reproduced, that is, si-flat - si-neutral. As a result, an interval of a reduced octave is formed between the melody and the harmonic accompaniment. Further, such a bright dissonance in the third element turns into the melodic structure of the third element.

The most striking and specific feature of the lyrical image in the ballet 'Seven Beauties' is a high artistic generalization. The latter highlights lyrical images in ballet as one of the main vectors of drama. It is this quality that allows one to explore the characteristic properties of the lyrical image in the ballet 'Seven Beauties' as an evolutionary stage in the process of the composer's style. Let us emphasize that the study of lyricism in Azerbaijani ballets requires a special approach. Lyrical imagery appears in every ballet. In each ballet, the lyrics take on individual features depending on the era and style of the composer. The creation of each new ballet was accompanied by the birth of certain new forms in the history of Azerbaijani ballet. 
The lyrical image as a spiritual value in the ballets of Fikret Amirov and Arif Melikov received its own special meaning. Thus, the individualization of lyrical images in ballets based on the works of Nizami is one of the main features of their embodiment. Directly connected with it is another feature that organizes the stylistic constant of ballets - this is the development, content dynamics, dramatic evolution of lyrical images.

The dramaturgy of Fikret Amirov's ballet 'Nizami' is constructed in such a way that the lyrical centre - the second act - contains the main lyrical content of the ballet.

F. Amirov, as an expert on Azerbaijani folk music culture, very subtly used the ethos of Azerbaijani modes in the disclosure and drama of the lyrical image of Afak. The characterization of the heroine Afak is based on the expressive intonation of the shoyah modes - zabul and shushter. And in the scene of Afak's death, a tragic melody, based on the chargah mode, comes to the fore.

The figurative and aesthetic parallels of the ballets of Azerbaijani composers, written based on the works of Nizami, converge on identical aspects of the interpretation of the lyrical image. Valuable are common human determinants, on the one hand, and national spiritual heritage, on the other. As it was said, in the ballets of Azerbaijani composers based on the poems of Nizami Ganjavi, the lyrical image is the lyrical center in the drama of ballets.

In the ballets of Kara Garayev, Fikret Amirov, Arif Melikov, the speech should be about deepening the lyrics, about a new understanding of the lyrical, of course, connected with the content of the ballets.

Turning to the lyrics in Azerbaijani ballets, we note that the lyrics create semantic correlations in the context of ballets that hold together the form and drama of the ballet as a whole. The above is comparable with Arif Melikov's ballet 'The Legend of Love'.

The semantics of the musical expressiveness of lyrical images in the ballet 'The Legend of Love' by Arif Melikov is complex, has both individual and genetic character. It is about reliance on lyrical expressiveness, which was formed in the context of Azerbaijani professional music.

'Adagio Farhada and Shirin' seems to embody several aspects of the lyrical content. Here there is a high lyrical feeling, nobility, restraint of emotions, and a 'high point' the of intensity of passions, and an exquisite, flexible lyrical lightness of a light joyful feeling. The specificity of intonational positioning is multifunctional. Here is a lyrical chant, and mournful intonations, and an emotional outburst of feelings. One can also observe a figurative transformation from a quiet chant to lyrical pathos. Thus, the expressive culmination is based on the main theme 'Adagio'. The lyric and dramatic content of 'Adagio Farhad and Shirin' is clearly revealed in the juxtaposition of emotional blocks. Thanks to this development, 'Adagio Farhada and Shirin' is permeated with movement, and the emotional 'colour' is deeply personal.

In the ballet "Babek" the continuity of the emotion development is brought to the fore. The flow of thought with a smooth flowing stream is replaced by dynamic growth, intense emotional development. The main pathos lies in the subtle fixation of various states of mind. As you know, a wide, intense development of emotion most often relies on the constant renewal of the melody without returning to the past stages.

An important stage in the development of the lyrical drama of the heroes is their third duet scene in the second act -'Farewell of Babek and Perishad'. The thematic 
fabric of the duet is saturated with acute impulsive intonations. The sound plan of the number breaks down into three thematic layers: an ostinato rhythmic background, second 'clusters' layering on the sustained sound ' $e$ ', and short motives - exclamations of woodwind instruments. Development is directed towards its increasing dramatization, the thematic of the scene is largely determined by the dynamics of various types of musical movement. In this free sound formation of form, various shades of mood are captured - from pensive-contemplative to excited-expressive.

The analysis shows that in the arsenal of the composer Akshin Alizade there were means that emphasized the specifics of national intonation and enhanced the expressive means of the lyrics in the ballet 'Babek'.

\section{Conclusions}

Let's list the typological parameters that unite the lyrical images of Azerbaijani composers:

1. Unity of national origins; artistic and historical ties with the primary source;

2. Intonational and typological connections of lyric poetry in ballets;

3. Features of musical and expressive means of lyrics in ballet miniatures by Azerbaijani composers. Unity and stylistic diversity;

4. Priority of genre-forming musical means in ballet miniatures;

5. The role of the complexity of the ballet performance in the embodiment of the lyrical image;

6. Ballet miniatures are distinguished by musical dynamics, certain properties of dramatic development, in which it becomes necessary to concentrate the maximum content in a miniature form;

7. Stage adequacy functions in performances. In this sense, the best traditions of the musical and choreographic school of Azerbaijan were embodied in ballet miniatures by Azerbaijani composers.

Musical and expressive means of lyrics have certainly evolved in Azerbaijani ballets. The functioning of the individual style of each of the outstanding composers of Azerbaijan has determined the features and means of embodying lyrical images in ballets. The specificity and character of these 'markers' of the lyrics in the music of Azerbaijani composers are based on the expressive means of the lyrics of the Azerbaijani national musical culture.

\section{References}

Abasova, E. A. (2000). O Novatorskikh Printsipakh v Tvorchestve Kara Karaeva [About Innovative Principles in the Work of Gara Garayev] [Brochure]. Baku Music Academy named after U. Hajibeyli [in Russian].

Abasova, E. A. (2004). Rol' Arifa Melikova v Razvitii Kompozitorskoi Shkoly Azerbaidzhana [The Role of Arif Melikov in the Development of the Composing School of Azerbaijan]. In Problemy Issledovaniya Azerbaidzhanskoi Natsional'noi Muzyki [Research Problems of Azerbaijani National Music] (Iss. 5, pp. 159-166). Adilogly [in Russian]. 
Abezgauz, I. V. (1967). O Garmonicheskom Yazyke Kara Karaeva [On the Harmonic Language of Kara Karaev]. In T. A. Lebedeva (Comp.), Muzyka i Sovremennost' [Music and Modernity] (Iss. 5, pp. 159-209). Muzyka [in Russian].

Aliev, R. M. (1991). Nizami Gyandzhavi [Nizami Ganjavi]. In Ganjavi Nizami, Sobranie Sochinenii $v$ Trekh Tomakh [Collected Works in Three Volumes] (K. Lipskerova \& S. Shervinskii, Trans.; Vol. 1; pp 3-9). Azernashr [in Russian].

Kosacheva, R. G. (1984). O Muzyke Zarubezhnogo Baleta, 1917-1939: Opyt Issledovaniya [About the Music of Foreign Ballet, 1917-1939: Research Experience]. Muzyka [in Russian].

Mahmudova, G. R. (2006). Genezis i Evolyutsiya Ostinatnosti v Azerbaidzhanskoi Muzyke [Genesis and Evolution of Astinance in Azerbaijani Music]. Nurlan [in Russian].

Nasirova, K. (2005). Balet "Tysyacha i Odna Noch" F. Amirova [Ballet "A Thousand and One Nights" by F. Amirov]. Tehsil [in Russian].

Nizami, Ganjavi. (1981). Stikhotvoreniya i Poemy [Poems and Poesy] (R. M. Aliev, Comps.). Sovetskii pisatel' [in Russian].

Skrebkov, S. (1973). Khudozhestvennye Printsipy Muzykal'nykh Stilei [Artistic Principles of Musical Styles]. Muzyka [in Russian].

\section{ЕВОЛЮЦІЯ ЛІРИЧНОГО ОБРАЗУ В БАЛЕТАХ АЗЕРБАЙДЖАНСЬКИХ КОМПОЗИТОРІВ}

Лала Гусейнлі

старший викладач; ORCID: 0000-0003-4158-1828; e-mail: I.d.hadjieva@gmail.com

Бакинська хореографічна академія, Баку, Азербайджан

\section{Анотація}

Мета дослідження - з'ясувати специфіку й виявити особливості еволюції ліричного образу в балетах азербайджанських композиторів. У статті підкреслено, що азербайджанський балет протягом історії азербайджанської композиторської школи незмінно функціонував як важлива складова музичної культури. Тема статті актуалізована в аспекті історичного підходу, оскільки кожен балет азербайджанських композиторів, з одного боку, відбивав значущі особливості художнього, історико-культурного контексту. 3 іншого боку, вивчення еволюції ліричного образу в балетах відображає динаміку розвитку азербайджанської композиторської школи. Крім того, подібна система в азербайджанських балетах репрезентує лінію художніх зв'язків азербайджанської культури. Методологія дослідження базується на використанні історичного підходу (для визначення основних дефініцій дослідження). Доцільність історичного методу зумовлена тим, що розвиток в просторі історичного часу має спиратися на певні базові категорії, які відображали б композиторську школу, її національну специфіку. Наукова новизна дослідження полягає в тому, що вперше проаналізовано особливості еволюції ліричного образу в азербайджанських балетах - від виникнення до сучасного функціонування; розглянуто нюанси стилетворення в азербайджанській композиторській школі в зазначеному аспекті, а також систематизовано певні художні процеси. Висновки. 
Доведено, що поєднання глибокого ліризму зі сповненими драматизму емоціями характерне для передачі лірики в драматургії балетів на всіх історичних етапах розвитку, в різних стилістичних контекстах. Ліричні образи в балетах азербайджанських композиторів мають подібні риси й зумовлені специфікою змістовності національного світосприйняття.

Ключові слова: балет; лірика; образ; еволюція; музика; історія; культура; композитор

\section{ЭВОЛЮЦИЯ ЛИРИЧЕСКОГО ОБРАЗА В БАЛЕТАХ АЗЕРБАЙДЖАНСКИХ КОМПОЗИТОРОВ}

\section{Лала Гусейнли}

старший преподаватель; ORCID: 0000-0003-4158-1828; e-mail: I.d.hadjieva@gmail.com

Бакинская хореографическая академия, Баку, Азербайджан

\section{Аннотация}

Цель исследования - выяснить специфику и выявить особенности эволюции лирического образа в балетах азербайджанских композиторов. В статье подчеркнуто, что азербайджанскийбалет напротяжении истории азербайджанской композиторскойшколы неизменно функционировал в качестве важного слагаемого музыкальной культуры. Тема статьи актуализирована в аспекте исторического подхода, поскольку каждый балет азербайджанских композиторов, с одной стороны, отражал значимые особенности художественного, историко-культурного контекста. С другой стороны, изучение эволюции лирического образа в балетах отражает динамику развития азербайджанской композиторской школы. Более того, подобная система в азербайджанских балетах репрезентирует линию художественных связей азербайджанской культуры. Методология исследования основана на использовании исторического подхода (для определения основных дефиниций исследования). Целесообразность исторического метода обусловлена тем, что развитие в пространстве исторического времени должно опираться на определенные базовые категории, которые отражали бы композиторскую школу, ее национальную специфику. Научная новизна исследования заключается в том, что впервые проанализированы особенности эволюции лирического образа в азербайджанских балетах - от возникновения до современного функционирования; рассмотрены нюансы стилеобразования в азербайджанской композиторской школе в указанном аспекте, а также систематизированы определенные художественные процессы. Выводы. Доказано, что сочетание глубокого лиризма с полными драматизма эмоциями является типичным для передачи лирики в драматургии балетов на всех исторических этапах развития, в разных стилистических контекстах. Лирические образы в балетах азербайджанских композиторов имеют схожие черты и обусловлены спецификой содержательности национального мировосприятия.

Ключевые слова: балет; лирика; образ; эволюция; музыка; история; культура; композитор 